Article

\title{
Highly Selective Oxidation of 5-Hydroxymethylfurfural to 5-Hydroxymethyl- 2-Furancarboxylic Acid by a Robust Whole-Cell Biocatalyst
}

\author{
Ran Cang ${ }^{1,+}$, Li-Qun Shen ${ }^{1,+}$, Guang Yang ${ }^{1}$, Zhi-Dong Zhang ${ }^{3}$, He Huang ${ }^{1,2, *}$ \\ and Zhi-Gang Zhang ${ }^{1, *(\mathbb{D})}$ \\ 1 School of Pharmaceutical Sciences, Nanjing Tech University, 30 Puzhu Road(S), Nanjing 211816, China; \\ crnj123@126.com (R.C.); shenliqun163@126.com (L.-Q.S.); qwe88227518@njtech.edu.cn (G.Y.) \\ 2 State Key Laboratory of Materials-Oriented Chemical Engineering, Nanjing Tech University, \\ 30 Puzhu Road(S), Nanjing 211816, China \\ 3 Institute of Microbiology, Xinjiang Academy of Agricultural Sciences, 403 Nanchang Rd, \\ Wulumuqi 830091, China; zhangzheedong@sohu.com \\ * Correspondence: huangh@njtech.edu.cn (H.H.); zhangzg@njtech.edu.cn (Z.-G.Z.) \\ + These authors contributed equally to this work.
}

Received: 16 May 2019; Accepted: 11 June 2019; Published: 12 June 2019

check for updates

\begin{abstract}
Value-added utilization of biomass-derived 5-hydroxymethylfurfural (HMF) to produce useful derivatives is of great interest. In this work, extremely radiation resistant Deinococcus wulumuqiensis $\mathrm{R} 12$ was explored for the first time as a new robust biocatalyst for selective oxidation of HMF to 5-hydroxymethylfuroic acid (HMFCA). Its resting cells exhibited excellent catalytic performance in a broad range ofpH and temperature values, and extremely high tolerance to HMF and the HMFCA product. An excellent yield of HMFCA (up to $90 \%$ ) was achieved when the substrate concentration was set to $300 \mathrm{mM}$ under the optimized reaction conditions. In addition, $511 \mathrm{mM}$ of product was obtained within $20 \mathrm{~h}$ by employing a fed-batch strategy, affording a productivity of $44 \mathrm{~g} / \mathrm{L}$ per day. Of significant synthetic interest was the finding that the D. wulumuqiensis R12 cells were able to catalyze the selective oxidation of other structurally diverse aldehydes to their corresponding acids with good yield and high selectivity, indicating broad substrate scope and potential widespread applications in biotechnology and organic chemistry.
\end{abstract}

Keywords: biocatalysis; extremophile; 5-hydroxymethylfurfural; 5-hydroxymethylfuroic acid; platform chemicals; whole cells

\section{Introduction}

The production of bio-fuels and chemicals from carbon-neutral and renewable biomass is attracting increasing interest [1-5]. Biomass is regarded as a sustainable resource from which some platform chemicals can be manufactured [6,7]. 5-hydroxymethylfurfural (HMF), derived from lignocellulosic materials via dehydration of carbohydrates, is one of the most important platform chemicals [8-10]. It has been listed as one of "Top 10+4" bio-based chemicals by the U.S. Department of Energy (DOE) [11], being applied in the synthesis of a variety of value-added pharmaceutical and biomaterial intermediates [12]. Due to its high reactivity, HMF is a versatile molecule that can be converted into various useful furan derivatives [12-14]. Its structure comprises a furan ring, an aldehyde group and a hydroxymethyl group which can be subjected to upgrading processes by selective redox reactions, leading to 5-hydroxymethylfuroic acid (HMFCA), 2,5-diformylfuran (DFF), 
5-formylfuroic acid (FFCA), 2,5-furandicarboxylic acid (FDCA), maleic anhydride (MA) and 2,5-bis (hydroxymethyl) furan (BHMF) (Scheme 1). Among these HMF derivatives, the completely oxidized product FDCA displays very promising application potential and may serve as a "greener" substitute for terephthalate in the manufacture of polyester and polyamide materials $[15,16]$. HMFCA is the oxidation product of the aldehyde group in HMF and a promising starting material for the synthesis of various polyesters [17]. It was reported that HMFCA can also be used as an antitumor agent and interleukin inhibitor $[18,19]$.

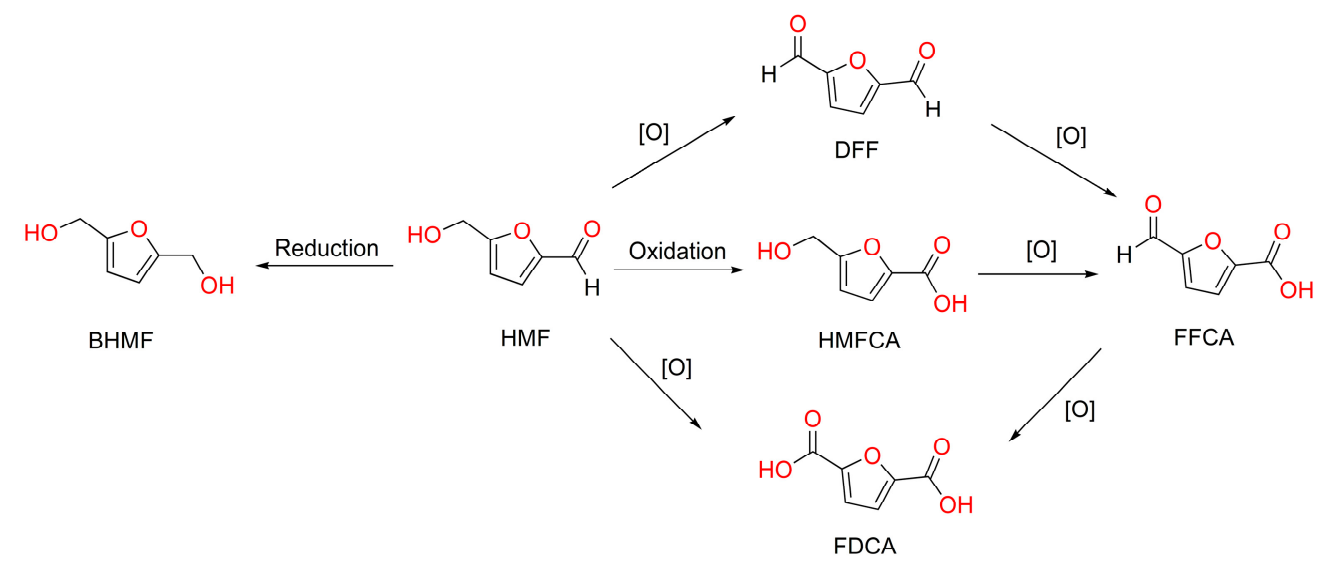

Scheme 1. Catalytic biotransformation of 5-hydroxymethylfurfural (HMF) into high value derivatives.

In order to form HMFCA, selective oxidation of the aldehyde group in HMF is required, while the alcohol group is left intact. Chemoselective oxidation methods are mainly used in the synthesis of HMFCA from HMF, in which noble metal catalysts are generally used [12,20-22]. Recently, HMF was selectively oxidized to HMFCA by an immobilized molybdenum complex in toluene within $3 \mathrm{~h}$, with a yield of approximately $87 \%$ [23]. Han et al. reported a selective and mild photocatalytic method for HMFCA synthesis from HMF under ultraviolet and visible light conditions with a yield of $90-95 \%$ [24]. In addition, the conversion of HMF to HMFCA via the Cannizzaro reaction is of great value $[25,26]$. However, the maximal selectivity of HMFCA was $50 \%$ due to the formation of an equimolar by-product.

Biocatalytic oxidation of HMF to HMFCA represents a promising alternative to chemical methods [14,27]. Biocatalysis offers many advantages, such as mild, environmentally friendly reaction conditions and often excellent selectivity, as well as high efficiency. However, compared to chemical methods, there are only a few reports on biotransformation of HMF to selectively form HMFCA in the literature [28-32]. In seminal work, Sheldon et al. reported the chloroperoxidase-catalyzed oxidation of HMF affording HMFCA with a selectivity of 25-40\% [31]. Krystof et al. reported lipase-mediated and peracid-assisted oxidation of the HMF process to produce HMFCA [32]. Recently, $\mathrm{Li}$ and co-workers made use of a molybdenum-dependent enzyme-xanthine oxidase from Escherichia coli-for the biocatalytic oxidation of HMF to form HMFCA, with $94 \%$ yield and 99\% selectivity [29].

Relative to the use of isolated enzymes, we believe that, in HMF oxidation, whole-cell biocatalysts have advantages. They are not only inexpensive and relatively stable, but they also do not require cofactor regeneration [27,33]. Biocatalysis is more efficient when recombinant whole cells that overexpress the enzyme(s) important for catalysis are used [34]. However, employing whole-cell biocatalysts for HMF oxidation is still challenging due to the well-known toxicity of HMF to microbial cells [30]. In addition, due to the variety of enzymes in microbial cells many side reactions are likely to occur during the process of HMF oxidation with formation of HMFCA [28]. Hence, exploring highly tolerant and selective microbial strains is crucial for the biotransformation of HMF into value-added derivative. To our knowledge, there are only a few studies on whole-cell-catalyzed selective oxidation of HMF to form HMFCA in the literature [28,30]; processes that are accompanied by a certain amount of HMF derivatives as byproducts. It was reported that some Pseudomonas strains have an HMF 
degradation pathway, in which HMF is converted to HMFCA as an intermediate [35-37]. A careful literature search did not reveal any studies describing the use of this system for the production of HMFCA. In 2010, Koopman et al. reported the production of 2,5-furandicarboxylic acid (FDCA) from HMF by using recombinant P. putida S12_hmfH. As part of this biotransformation, HMFCA hardly accumulated, leading to a mixture of other metabolites [38,39]. Therefore, in the challenging quest to obtain large amounts of pure HMFCA, the use of the Pseudomonas strain metabolic pathway is not feasible. Moreover, long standing issues still exist, such as low substrate loading, substrate toxicity and insufficient selectivity, etc. Therefore, searching for new and robust biocatalytic systems with high selectivity is a demanding task.

Extremophiles are organisms that have evolved to thrive under one or more extreme adverse environmental conditions where other organisms cannot survive [40,41]. They are regarded as an ideal and valuable source of biocatalysts, allowing biotransformation under relatively harsh industrial conditions [42-44]. Nevertheless, employing whole-cells or isolated enzymes derived from extremophiles for biocatalysis in a general manner is just beginning to be implemented experimentally. Recently, a Deinococcus sp, designated as Deinococcus wulumuqiensis R12, was isolated from radiation-polluted soil $[45,46]$. Previous studies showed that it is phylogenetically more closely related to a prototype strain of the Deinococcus genus, namely Deinococcus radiodurans R1 [47]. It was found that this strain was capable of producing carotenoids with good yield, and related biosynthesis genes were subsequently cloned and heterogeneously expressed in E. coli. by Xu et al. [48]. Furthermore, its whole genome was sequenced by Huang et al. [49]. Recently, genes encoding heat shock proteins from D. wulumuqiensis R12 were introduced into Clostridium acetobutylicum ATCC824 in order to improve the robustness and butanol titers of host cells [50]. Considering the robustness of D. wulumuqiensis R12, it would be of great interest to explore the catalytic properties of its whole cells in biotransformation or bioconversion.

In this study, we report that the radiation resistant strain $D$. wulumuqiensis $\mathrm{R} 12$ that can indeed be used as a whole-cell biocatalyst in HMFCA synthesis by selective oxidation of HMF (Scheme 2). The catalytic properties of this strain were evaluated in the transformation of HMF, and the reaction conditions were optimized. In addition, the substrate scope of this new whole-cell biocatalyst was also investigated.

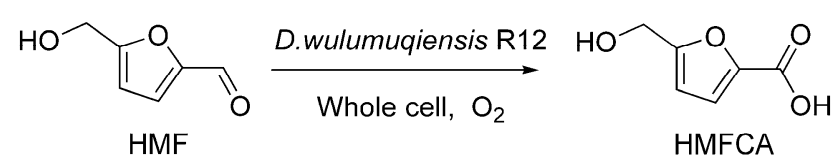

Scheme 2. Chemoselective oxidation of MF to 5-hydroxymethylfuroic acid (HMFCA) with whole D. wulumuqiensis $\mathrm{R} 12$ cells.

\section{Results and Discussion}

\subsection{Growing and Resting Deinococcus Cells as Catalysts in HMF Oxidation with Selective Formation of HMFCA}

Similar to the prototype strain of the Deinococcus genus, D. radiodurans R1, D. wulumuqiensis $\mathrm{R} 12$ is also well known for its excellent ability to resist extremely high doses of gamma and UV radiation [45]. In order to explore its potential applications in biocatalysis, growing and resting cells of this strain were applied as biocatalysts in the conversion of HMF to form HMFCA. As shown in Figure 1a, $100 \mathrm{mM}$ of the HMF substrate were converted almost completely within $12 \mathrm{~h}$ using resting cells, whereas growing cells gave only a $32 \%$ yield at a prolonged reaction time of $36 \mathrm{~h}$. Resting cells enabled a much higher yield with more than $98 \%$ of HMFCA and a trace amount of 2,5-bis (hydroxymethyl) furan (BHMF) as sole byproduct, indicating excellent chemoselectivity in this biocatalytic process. Increasing substrate concentration further did not affect the selectivity of the resting cells (Figure S2). Considering the reported degradation mechanism of HMF in microbial cells [51], it is reasonable to speculate 
that the intermediate HMF alcohol (from HMF reduction) was almost completely oxidized in a very short time to form the final HMFCA, or the HMF substrate was oxidized directly-which constitutes a different mechanistic hypothesis. However, to validate this inference, more efforts need to be invested.
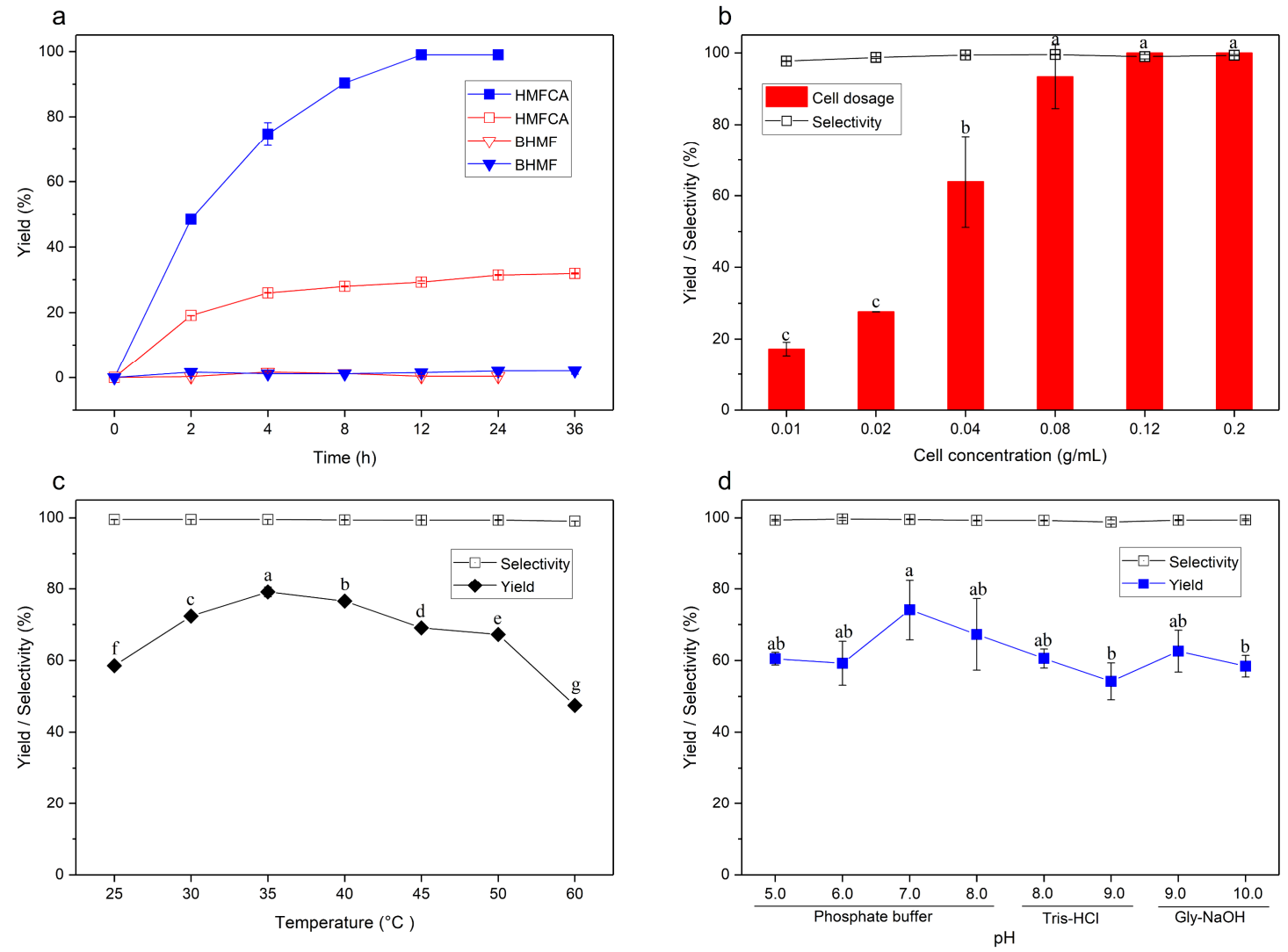

Figure 1. The influence of various factors on HMFCA synthesis by HMF. General conditions unless otherwise stated: $100 \mathrm{mM} \mathrm{HMF}, 0.12 \mathrm{~g} / \mathrm{mL}$ microbial cells, $100 \mathrm{mM}$,pH 7.4, phosphate buffer, $850 \mathrm{rpm}$, $30{ }^{\circ} \mathrm{C}$, $4 \mathrm{~h}$ reaction time. (a) Resting (solid symbols) and growing cells (open symbols), wherein tryptone glucose yeast extract (TGY) culture was used when growing cells were employed under $200 \mathrm{rpm}, 30{ }^{\circ} \mathrm{C}$; (b) cell concentration; (c) temperature; and (d)pH values. Time courses of HMF biotransformation using resting (solid symbols) and growing cells (open symbols).

In addition, we were pleased to discover the performance of two other Deinococcus strains stored in our lab, D. radiodurans R1 and Deinococcus xibeiensis R13, which were also used in the biocatalytic oxidation of HMF to HMFCA. It was found that both radiation resistant strains selectively oxidized HMF with formation of HMFCA. The conversions achieved by D. radiodurans $\mathrm{R} 1$ and $D$. xibeiensis $\mathrm{R} 13$ were slightly lower than that of $D$. wulumuqiensis R12 under the same reaction conditions (Figure S3). These results suggest that the $D$. wulumuqiensis $\mathrm{R} 12$ cells act as a catalytic system with high activity and excellent chemoselectivity in the oxidation of HMF to HMFCA. Its catalytic properties were subsequently investigated in greater detail (Figure 1).

\subsection{Effect of Cell Dosage in the Reaction System for HMFCA Synthesis}

Figure $1 \mathrm{~b}$ shows the influence of microbial cell dosage on HMFCA synthesis based on selective oxidation of HMF. The yield of HMFCA increased steadily from $18 \%$ to $99 \%$ with increasing cell dosage in the presence of $100 \mathrm{mM}$ of HMF substrate. The maximal yield of $99 \%$ was achieved when the cell dosage reached $0.12 \mathrm{~g} / \mathrm{mL}$, and further increasing did not improve the HMFCA yield, indicating that the biocatalyst was potentially saturated by substrate under the given reaction conditions. Our results imply that the conversion of HMF to HMFCA correlates with the cell dosage employed 
in the biocatalytic system. A small amount of cell dosage was required to reach maximal conversion when the substrate concentration decreased to $40 \mathrm{mM}$ under the same reaction conditions (Figure S4). In addition, cell dosage had no significant effect on the selectivity of the reactions ( $>98 \%)$. A higher cell dosage may result in higher viscosity, however, which could impact mass transfer of the reaction mixture. Thus, the optimal cell dosage of $0.12 \mathrm{~g} / \mathrm{mL}$ wet cells was used in subsequent experiments.

\subsection{Effect of Temperature and $p H$ on HMFCA Synthesis}

The influence of temperature and $\mathrm{pH}$ on HMFCA synthesis in the whole-cell catalyzed oxidation of HMF was also studied. As shown in Figure 1c, the effect of reaction temperature on HMF selective oxidation was determined by performing the transformation at different temperatures. Remarkably, the microbial cell biocatalyst showed considerable activity at a broad temperature range, from 25 to $60{ }^{\circ} \mathrm{C}$. The maximal substrate conversion of $79 \%$ was obtained at $35^{\circ} \mathrm{C}$ after $4 \mathrm{~h}$ in the presence of $100 \mathrm{mM}$ HMF substrate. In addition, even at $50{ }^{\circ} \mathrm{C}, 67 \%$ of the HMF substrate was converted to HMFCA, which is in accord with an early report that $D$. wulumuqiensis $\mathrm{R} 12$ has a broad growth temperature range [45]. Slightly decreased conversion is possibly due to the inactivation of the enzymes in the microbial cells at $60^{\circ} \mathrm{C}$. It should be mentioned that HMFCA was obtained as essentially the only oxidative product-with a yield of $99 \%$-in the reaction within the temperature range of $25^{\circ} \mathrm{C}$ to $60^{\circ} \mathrm{C}$, indicating excellent catalytic selectivity of the whole-cell biocatalyst. Considering the thermostability of cells and energy efficiency, a temperature of $35^{\circ} \mathrm{C}$ was set for subsequent experiments.

In addition, we further studied the $\mathrm{pH}$ profile of the whole-cell catalyst in HMFCA synthesis via selective oxidation of HMF (Figure 1d). It was found that the microbial cells had a broadpH activity profile and exhibited a particularly good catalytic performance in the $\mathrm{pH}$ range of 5.0 to 10.0. The best yield of $81 \%$ was achieved in $100 \mathrm{mM}$ phosphate buffer at a pH 7.0 after $4 \mathrm{~h}$. Interestingly, a conversion percentage of $60 \%$ and $58 \%$ was obtained in phosphate buffer ofpH 5.0 and Gly-NaOH buffer ofpH 10.0, respectively, after a reaction time of $4 \mathrm{~h}$. In addition, it appeared that the buffer types had a moderate influence on the conversion of HMF, as a yield of $54 \%$ was obtained in Tris- $\mathrm{HCl}$ buffer (pH 9.0), compared to 63\% in Gly-NaOH buffer at the samepH . One should not be surprised that D. wulumuqiensis $\mathrm{R} 12$ cells are able to resist such harsh reaction conditions with extremepH values. In their studies, Wang et al. reported that the D. wulumuqiensis R12 strain is able to grow in a widepH range from 5.0 to 12.0 [45]. Compared to Comamonas testosterone SC1588, which has been applied in HMFCA synthesis from HMF [28], D. wulumuqiensis R12 cells showed higher tolerance to extremepH values. Therefore, the optimalpH value of 7.0 was selected for all subsequent experiments.

\subsection{Inhibitory and Toxic Effect of Substrate}

HMF is a well-known toxic inhibitor of microbial cells, inhibiting their growth and hindering their upgrading of HMF by whole-cell biocatalysis [52]. The catalytic performance of $D$. wulumuqiensis R12 cells towards HMF under varying concentrations was therefore tested. As shown in Figure 2a, HMFCA was synthesized in $99 \%$ yield within $12 \mathrm{~h}$ when the substrate concentration was $150 \mathrm{mM}$. However, the yield decreased slightly to $81 \%$ at the substrate concentration of $200 \mathrm{mM}$. The yield decreased gradually in the substrate concentration range of $250-1000 \mathrm{mM}$. Remarkably, $41 \%$ yield of HMFCA was obtained when the substrate concentration reached $500 \mathrm{mM}$, and a yield of $23 \%$ was observed at the substrate concentration of $1000 \mathrm{mM}$. The essentially complete selectivity remained almost constant at these varying substrate concentrations. 

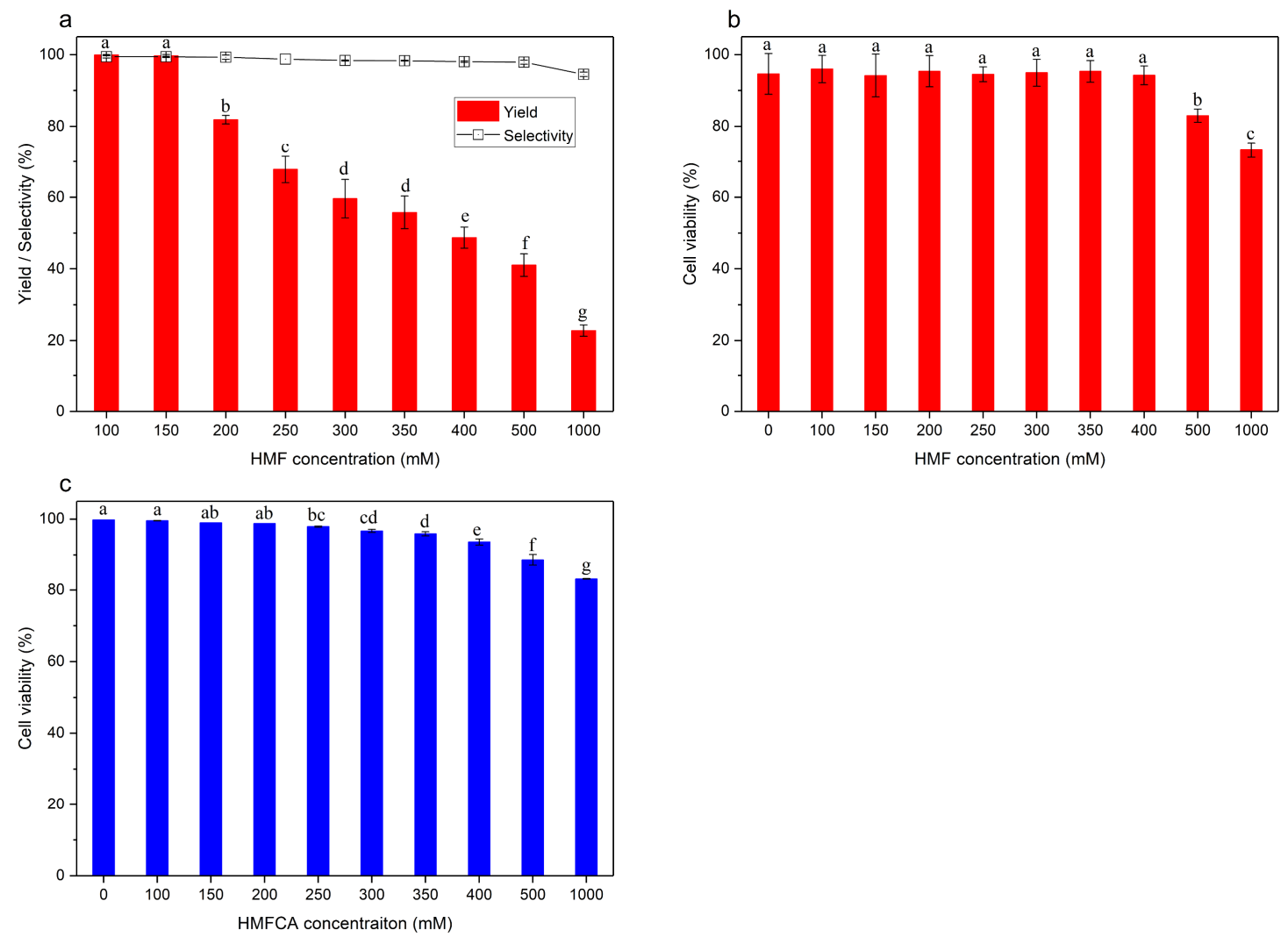

Figure 2. Effects of HMF concentration on (a) HMFCA synthesis and (b) cell viability. Reaction conditions: $0.12 \mathrm{~g} / \mathrm{mL}$ microbial cells, in phosphate buffer $(100 \mathrm{mM}, \mathrm{pH} 7.0)$ under $850 \mathrm{rpm}$ and $35{ }^{\circ} \mathrm{C}$. Fresh harvested cells incubated without HMF/HMFCA under identical conditions were used as a control. Reaction periods: $12 \mathrm{~h}$ for $100 \mathrm{mM} 150 \mathrm{mM} ; 24 \mathrm{~h}$ for $200 \mathrm{mM}, 250 \mathrm{mM}$; and $36 \mathrm{~h}$ for $300 \mathrm{mM}, 350 \mathrm{~m}$, $400 \mathrm{mM}, 500 \mathrm{mM}, 1000 \mathrm{mM}$. (c) Effects of the product concentration on cell viability. HMFCA was incubated for $24 \mathrm{~h}$ under the same conditions.

It is well known that the cytotoxicity of HMF to microbial cells is a key parameter in whole-cell biocatalytic conversion of HMF. As shown in Figure 2b, the effect of substrate concentration on cell viability was investigated by using a cell viability assay. The microbial cells were incubated with varying concentrations of HMF under the usual reaction conditions, and the cell viability was subsequently measured using an Annexin V-FITC/PI Apoptosis Detection Kit. Microbial cells incubated in buffer without substrate under the same reaction condition were used as a control. Good cell viability (94\%) was unexpectedly obtained in the presence of $400 \mathrm{mM}$ substrate, which was not significantly different than that of the control. This result suggests that the microbial cells can tolerate as much as $400 \mathrm{mM}$ of HMF substrate without losing viability. Further increasing HMF concentration to $500 \mathrm{mM}$ led only to a slight decrease in cell viability to $83 \%$. When $1000 \mathrm{mM}$ of HMF substrate was used, $73 \%$ cell viability was still observed, indicating that $D$. wulumuqiensis $\mathrm{R} 12$ is extremely tolerant to HMF substrate. However, the conversion of HMF in the oxidation reaction decreased dramatically with increased substrate concentration. Since detailed toxic mechanisms of HMF to microbial cells are not completely understood, nor the reason for the extreme resistance of D. wulumuqiensis R12 cells to harsh environmental factors, the present results are not considered surprising.

\subsection{Inhibitory and Toxic Effect of the HMFCA Product}

In the oxidation of HMF to HMFCA, the product is an acidic compound harboring a carboxylic and hydroxyl group. In our work, the $\mathrm{pH}$ of the reaction system decreased over the reaction time due to the accumulation of the HMFCA product. This situation could conceivably become critical when high concentrations of substrate are produced. Thus, it would be of great interest and importance to 
investigate the possible inhibition and toxicity of the product towards microbial cells. Microbial cells incubated in phosphate buffer without the product was used as the control for such investigations. Based on the high cell viability ( $>93 \%$ ), which was comparable to that of the control, there appeared to be no significant toxicity towards the microbial cells at HMFCA product concentrations less than $400 \mathrm{mM}$, as shown in Figure 2c. However, a product amount of $500 \mathrm{mM}$ resulted in slight toxicity, as the cell viability value decreased to $87 \%$. A further increased product concentration of $1000 \mathrm{mM}$ led to significant toxicity of the microbial cells, with a viability of $84 \%$. To our surprise, the data showed that the product toxicity to the viability of microbial cells was not as high as expected, even at extremely high concentrations. Considering that $D$. wulumuqiensis R12 is a robust strain, able to grow in a broad range ofpH values, one should not be surprised that the microbial cells are highly resistant to HMFCA production, with excellent cell viability at extremely high product concentrations. Further product toxicity tests with still higher concentrations were not performed, as the conversion of HMF was already very low at the substrate concentration of $1000 \mathrm{mM}$.

\subsection{Manufacture of HMFCA Under Optimized Conditions}

Obtaining large amounts of HFMCA is highly desired in biocatalytic oxidation of HMF by whole-cell biocatalysis, with great potential applications in industrial production. Therefore, further enhancement of the catalytic performance of $D$. wulumuqiensis R12 was investigated by optimizing the biocatalytic parameters of the conversion process. It was found that the HMFCA product yields were affected significantly by increasing the substrate concentration. For example, due to the known negative effect of HMF, the yield of HMFCA decreased significantly when HMF concentrations were higher than $300 \mathrm{mM}$ (Figure 2a). Based on the catalytic properties of this strain, increasing the dosage of microbial cells in the reaction may further enhance the HMFCA yield. Recently, Zhang et al. reported that improved synthesis of HFMCA from HMF was obtained by tuning the $\mathrm{pH}$ of the reaction mixture using $\mathrm{NaOH}$ solution during the catalytic process [28]. Thus, we decided to employ the same strategy. In addition, it has been reported that adding furfural and furfural alcohol as inducers during cultivation of microbial cells for biocatalysis can trigger the expression of the enzymes responsible for HMF oxidation, which can facilitate HMFCA production. Therefore, three strategies (increasing microbial cell dosage, using inducing cells and tuningpH of reaction mixture) were applied in subsequent studies.

Increasing the dosage of microbial cells proved to be effective for enhancing the yield of HMFCA (Figure S4a). For example, in the presence of $300 \mathrm{mM} \mathrm{HMF}$, the yield of HMFCA increased considerably from $59 \%$ to $71 \%$ when the concentration of cells increased from $0.12 \mathrm{~g} / \mathrm{mL}$ to $0.2 \mathrm{~g} / \mathrm{mL}$. A further increase in cells dosage was not performed considering the negative effect of higher viscosity in the reaction mixture. On the other hand, influencing the expression of cells by the use of furfural and furfural alcohol for enhancing the yield of HMFCA proved not to be effective (Figure S4b). The reason for this might be that enzymes in D. wulumuqiensis R12 responsible for HMF oxidation are expressed constitutively. Finally, $\mathrm{pH}$ tuning was found to be an effective method for improving the yield of HMFCA (Figure S4c). Thus, the $\mathrm{pH}$ of the reaction mixture was tuned to approximately 7.0 using a $\mathrm{NaOH}$ solution. Compared with the control withoutpH tuning, the HMFCA yield improved from $66 \%$ to $83 \%$ in the presence of $300 \mathrm{mM} \mathrm{HMF}$ substrate, and from $48 \%$ to $65 \%$ at an HMF concentration of $500 \mathrm{mM}$.

Therefore, both increasing the dosage of microbial cells and $\mathrm{pH}$ tuning was applied together for enhancing the production of HMFCA. As shown in Figure 3, at a high HMFCA concentration, a yield of $90 \%$ was achieved after $36 \mathrm{~h}$ when the substrate concentration was $300 \mathrm{mM}$. This demonstrates the considerable effectiveness of the combined strategy. In addition, the oxidative conversion of HMF to HMFCA reached $80 \%$ in the presence of $350 \mathrm{mM}$ HMF after $48 \mathrm{~h}$. When the concentration of HMF was set to $500 \mathrm{mM}, 66 \%$ of the substrate was still converted after $48 \mathrm{~h}$, but further prolonged reaction times did not lead to an increase in HMFCA yield. 


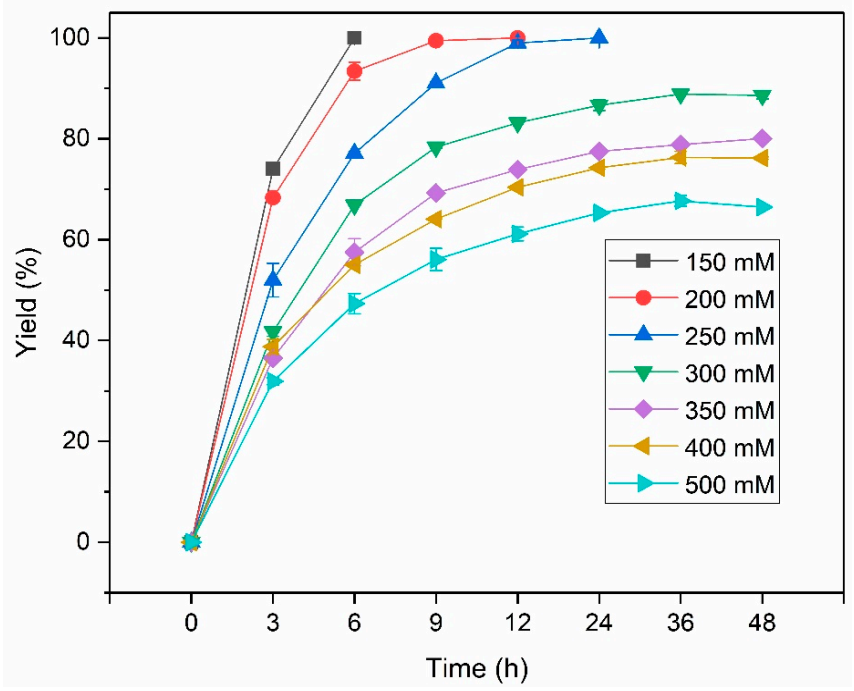

Figure 3. Synthesis of HMFCA under optimized conditions. Reaction conditions: HMF of the designated concentration, $0.2 \mathrm{~g} / \mathrm{mL}$ microbial cells, $5 \mathrm{~mL}$ phosphate buffer $(100 \mathrm{mM}, \mathrm{pH} 7.0), 35^{\circ} \mathrm{C}$, and $850 \mathrm{rpm}$. Tuning the $\mathrm{pH}$ of the reaction system to approximately 7.0 occurred every $3 \mathrm{~h}$ in the first $12 \mathrm{~h}$, and then every $12 \mathrm{~h}$ in the $36 \mathrm{~h}$ that followed.

Compared with previous reported biocatalysis results, the data obtained in this work proved to be more efficient and selective because of a higher substrate concentration and simpler catalytic process. As shown in Table 1, the substrate concentrations used in the reported biocatalytic routes were still very low and co-enzymes were usually required when isolated enzymes were applied. Although C. testosterone SC1588 cells also display good selectivity and high HMF tolerance, its catalytic performance is highly sensitive topH [28]. Thus, a considerable amount of histidine co-substrate is required for efficient selective oxidation of HMF. The extreme environment-derived $D$. wulumuqiensis R12 strain used in this work exhibited excellent resistance to highpH and temperatures, and proved to be a robust biocatalyst for HMFCA synthesis by way of selective oxidation of HMF.

Table 1. HMFCA synthesis via HMF oxidation by various biocatalytic systems.

\begin{tabular}{|c|c|c|c|c|}
\hline Biocatalysts & Reaction Conditions & $t(h)$ & $\begin{array}{l}\text { Yield } \\
(\%)\end{array}$ & Ref. \\
\hline Chloroperoxidase & $50 \mathrm{mM} \mathrm{HMF}, 1$ equiv $\mathrm{H}_{2} \mathrm{O}_{2}$ per $2 \mathrm{~h}$ & 2.5 & $25-40$ & [31] \\
\hline Serratia liquefaciens LF14 & $\begin{array}{l}10 \mathrm{mM} \text { HMF, } 18.2 \mathrm{mg} / \mathrm{mL} \text { dry cells, in phosphate buffer } \\
50 \mathrm{mM} \text { HMF, } 10 \mathrm{mg} / \mathrm{mL} \text { catalase, addition of aqueous }\end{array}$ & 1 & 97 & [30] \\
\hline Immobilized lipase B & $\begin{array}{l}\mathrm{H}_{2} \mathrm{O}_{2}(30 \% \mathrm{v} / \mathrm{v}) \text { hourly, reaction media: acyl } \\
\text { butyrate/tBuOH }(1: 1 \mathrm{v} / \mathrm{v}), 40^{\circ} \mathrm{C}\end{array}$ & 24 & 76 & {$[32]$} \\
\hline Xanthine oxidase $(\mathrm{XO})$ & $\begin{array}{l}26 \mathrm{mM} \text { HMF, } 5.6 \mathrm{U} \text { E. coli } \mathrm{XO}, 1.1 \mathrm{mg} \text { catalase, } \\
\text { phosphate buffer, } 37^{\circ} \mathrm{C}, 150 \mathrm{rpm} \text {, air bubbling }\end{array}$ & 7 & 94 & [29] \\
\hline Comamonas testosterone SC1588 & $\begin{array}{l}160 \mathrm{mM} \text { HMF, } 30 \mathrm{mg} / \mathrm{mL} \text { induced microbial cells, } \\
\text { phosphate buffer, } 20 \mathrm{mM} \text { histidine, } 150 \mathrm{rpm}, 30^{\circ} \mathrm{C} \text {, } \\
\text { tuningpH of the reaction mixture to approximately } 7.0 \\
\text { every } 24 \mathrm{~h} \text {. }\end{array}$ & 36 & 98 & [28] \\
\hline Aldehyde dehydrogenases & $\begin{array}{l}20 \mathrm{mM} \text { HMF, } 10 \mu \mathrm{M} \text { catalase, } 5 \mu \mathrm{M}[\mathrm{NOx}], 100 \mu \mathrm{g} / \mathrm{mL} \\
{[\mathrm{DTT}], 0.5 \mathrm{mM}\left[\mathrm{NAD}^{+}\right] \text {, phosphate buffer, }} \\
40^{\circ} \mathrm{C}, 180 \mathrm{rpm}\end{array}$ & 24 & 91 & [53] \\
\hline D. wulumuqiensis $\mathrm{R} 12$ & $\begin{array}{l}300 \mathrm{mM} H \mathrm{HM}, 200 \mathrm{mg} / \mathrm{mL} \text { microbial cells, phosphate } \\
\text { buffer, } 850 \mathrm{rpm}, 35^{\circ} \mathrm{C} \text {, tuningpH of the reaction mixture } \\
\text { to approximately } 7.0 \text { every } 3 \mathrm{~h} \text {. }\end{array}$ & 36 & 90 & This work \\
\hline
\end{tabular}

\subsection{Efficient Synthesis of HMFCA by a Fed-Batch Strategy}

As mentioned above, excellent yields of HMFCA from selective oxidation of HMF were obtained under optimized conditions. It is highly desirable to manufacture HMFCA on a large scale in an effort to create a practical biocatalytic process. Thus, by applying a fed-batch strategy, in which HMF substrate was added continuously, the accumulation of high concentrations of product was achieved. 
Figure 4 shows the results of biocatalytic synthesis of high concentrations of HMFCA. It was found that $511 \mathrm{mM}$ of product was produced within $20 \mathrm{~h}$ after three-batch feeding of HMF, affording a total yield of $85 \%$ and a productivity of approximately $44 \mathrm{~g} / \mathrm{L}$ per day. Only $4 \mathrm{mM}$ of BHMF was observed as the sole byproduct $(<1 \%)$. Chemoselectivity towards the target product reached more than $99 \%$. In addition, a decrease in yield of HMFCA in each batch feeding was observed, indicating possible substrate and/or product inhibition in the whole-cell biocatalyst. An attempt to improve the yield of HMFCA further in this fed-batch process was performed by prolonging the reaction time, but no significant improvement was observed (Data not shown).

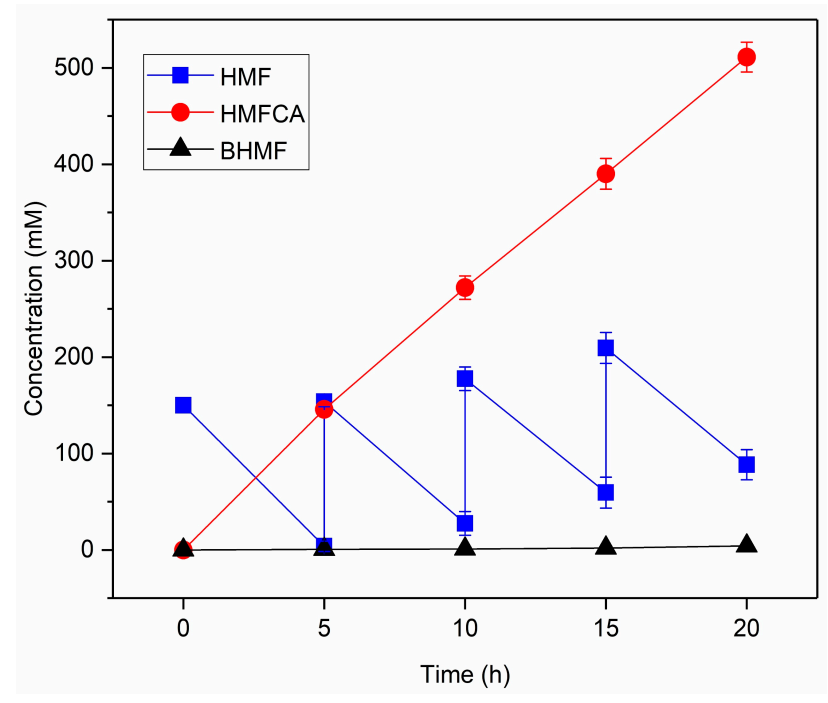

Figure 4. Synthesis of HMFCA by a fed-batch method. Reaction conditions: $150 \mathrm{mM} \mathrm{HMF}, 0.2 \mathrm{~g} / \mathrm{mL}$ microbial cells, $5 \mathrm{~mL}$ phosphate buffer $(100 \mathrm{mM}, \mathrm{pH} 7.0), 35^{\circ} \mathrm{C}$, and $850 \mathrm{rpm}$. In each cycle of $5 \mathrm{~h}$, $0.75 \mathrm{mmoL}$ of HMF was added.

\subsection{Exploring the Substrate Scope of D. wulumuqiensis R12}

In order to examine the substrate spectrum of this novel whole-cell biocatalyst, a set of structurally unique aldehyde compounds was applied in the oxidation reactions catalyzed by D. wulumuqiensis R12 cells (Scheme 3). Considering possible solubility and toxicity effects, proper concentrations of these aldehyde compounds were applied. The results showed that the whole cells of the strain readily accept furfural as a substrate, thereby enabling an efficient synthesis of furoic acid ( $>99 \%$ yield). Furoic acid can be used in the pharmaceutical, agrochemical, and flavor industries [9]. In the case of aldehydes containing an additional hydroxyl group, the microbial cells proved to be strictly chemoselective for the aldehyde group, affording the corresponding carboxylic acids with good to excellent yields (Table 2). For example, oxidation of DFF and FFCA to FDCA was achieved with $100 \%$ and $63 \%$ yields, respectively. Due to solubility issues, higher DFF substrate concentrations were not applied. We also discovered that the aldehyde group of vanillin could be selectively oxidized by the microbial cells to vanillic acid. Vanillic acid has important applications in the pharmaceutical industry, and also as a monomer in polyester synthesis [54]. In addition, terephthalic acid and p-hydroxybenzoic acid were also prepared by selective oxidation of the corresponding aldehydes. In short, the results showed that $D$. wulumuqiensis $\mathrm{R} 12$ as a biocatalyst has an amazingly broad substrate spectrum. 
<smiles>O=Cc1ccco1</smiles>

Furfural<smiles>COc1cc(C=O)ccc1O</smiles>

Vanillin<smiles>O=C(O)c1ccco1</smiles>

Furoic acid<smiles>COc1cc(C(=O)O)ccc1O</smiles>

Vanillic acid<smiles>O=Cc1ccc(O)cc1</smiles><smiles>O=Cc1ccc(C=O)cc1</smiles>

p-Hydroxybenzaldehyde Terephthaldehyde<smiles>O=C(O)c1ccc(O)cc1</smiles>

4-Hydroxybenzoic acid<smiles>O=C(O)c1ccc(C(=O)O)cc1</smiles>

Terephthalic acid

Scheme 3. Aldehyde substrates used and products obtained in biocatalytic oxidation by D. wulumuqiensis R12 whole cells.

Table 2. Whole-cell biocatalytic oxidation of aldehydes.

\begin{tabular}{ccccc}
\hline Entry & Substrate & Substrate Concentration $\mathbf{( m M )}$ & Product & Yield (\%) \\
\hline 1 & Furfural & 100 & Furoic acid & $>99$ \\
2 & DFF & 30 & FDCA & $>99$ \\
3 & FFCA & 100 & FDCA & 63 \\
4 & Vanillin & 5 & Vanillic acid & $>99$ \\
5 & $p$-Hydroxybenzaldehyde & 5 & 4-Hydroxybenzoic acid & 70 \\
6 & Terephthaldehyde & 2 & Terephthalic acid & $>99$ \\
\hline
\end{tabular}

Reaction conditions: $0.12 \mathrm{~g} / \mathrm{mL}$ microbial cells, $5 \mathrm{~mL}$ of phosphate buffer $(100 \mathrm{mM}, \mathrm{pH} 7.0), 850 \mathrm{rpm}, 35^{\circ} \mathrm{C}$ for $12 \mathrm{~h}$.

\section{Materials and Methods}

\subsection{Chemicals and Strains}

Extremely radiation resistant strains D. wulumuqiensis R12 (DSM 28115T), D. radiodurans R1 (ATCC NO.13939), and D. xibeiensis R13 (NRBC 105666T) were acquired from Zhi-Dong Zhang at the Institute of Microbiology, Xinjiang Academy of Agricultural Sciences in China and stored in our laboratory. The GenBank accession number for the 16S rDNA sequence was KJ784486, while the whole genome sequence was APCS01000000.

HMF (97\%) and HMFCA (97\%) were purchased from Macklin Biochemical Co., Ltd (Shanghai, China). FDCA (98\%), DFF (98\%) and furfural (98\%) were obtained from Aladdin Biochemical Technology Co., Ltd (Shanghai, China). BHMF (98\%) was purchased from Ark Pharm, Inc (Arlington Heights, IL, USA). HMFCA (97\%) was obtained from J\&K Scientific Ltd (Beijing, China). Both furfuryl alcohol (99.5\%) and furoic acid (98\%) were obtained from TCI (Shanghai, China). Annexin V-FITC/PI Apoptosis Detection Kit was purchased from Nanjing KeyGen Biotech. Co. Ltd. (Jiangsu, China) for the cell viability assay. 


\subsection{Cultivation of D. wulumuqiensis R12 Cells}

The glycerol stock of $D$. wulumuqiensis $\mathrm{R} 12$ was pre-cultivated at $30^{\circ} \mathrm{C}, 200 \mathrm{rpm}$ for $24 \mathrm{~h}$ in tryptone glucose yeast extract (TGY) medium containing $0.5 \%$ tryptone, $0.1 \%$ glucose, and $0.3 \%$ yeast extract. Then, $1 \%$ of the overnight preculture was transferred to fresh TGY medium. The culture was incubated at $30^{\circ} \mathrm{C}, 200 \mathrm{rpm}$ for $48 \mathrm{~h}$ and was centrifugated under $5000 \mathrm{rpm}$ for $10 \mathrm{~min}$ to harvest cells. The cell pellet was washed twice with $100 \mathrm{mM}$ phosphate buffer ( $\mathrm{pH}$ 7.4) and resuspended in phosphate buffer with a final cell concentration of $0.12 \mathrm{~g} / \mathrm{mL}$ (cell wet weight).

\subsection{General Procedure for the Biocatalytic Oxidation of Aldehyde Substrates}

Five milliliters of phosphate buffer $(0.1 \mathrm{M}, \mathrm{pH} 7.0)$ containing the designated amounts of microbial cells (cell wet weight) and substrates was incubated at $35{ }^{\circ} \mathrm{C}$ and $850 \mathrm{rpm}$ for a given reaction time. Aliquots of the reaction mixture were withdrawn at specified reaction times and diluted with the phosphate buffer prior to high-performance liquid chromatography (HPLC) assays. The conversion of HMF and other aldehydes by biocatalytic oxidation was defined as the percentage of the consumed substrate amount in the initial amount. The selectivity of the reaction was defined as the ratio of HMFCA product amount to the sum of all the products. The yield was defined as the percentage of the measured product amount in the theoretical product amount based on the initial amount of HMF.

$$
\% \text { yield }=\frac{\text { Actual yield }}{\text { Theoretical yield }} \times 100 \%
$$

\subsection{Analytical Method}

The reaction products were analyzed by HPLC following a previously reported method with slight modifications [28]. Briefly, a reverse-phase HPLC (Thermo Fisher ultimate 3000), equipped with Sepax GP-C18 column $(4.6 \mathrm{~mm} \times 250 \mathrm{~mm}, 5 \mu \mathrm{m})$, was used at $25^{\circ} \mathrm{C}$. The mobile phase was the gradient of acetonitrile in $20 \mathrm{mM} \mathrm{KH}_{2} \mathrm{PO}_{4}$ (pH 6.0) at a flow of $1.0 \mathrm{~mL} \mathrm{~min}^{-1}$, increasing from $10 \%$ to $24 \%$ within $7 \mathrm{~min}$ and from $24 \%$ to $10 \%$ within $3 \mathrm{~min}$. The HPLC retention time of the HMFCA product and HMF were $2.90 \mathrm{~min}$ and $6.20 \mathrm{~min}$, respectively. All experiments were performed in triplicate and mean values are presented. Data are expressed as the mean \pm standard deviation. Duncan's multiple range test (using SPSS software 16.0, Chicago, IL, USA) was used to analyze the statistical significance of differences between the groups. A significance difference was judged to exist at a level of $p<0.05$. HPLC runs are shown in Figure S1.

\subsection{Cell Viability Assay}

Cell viability assay experiments were performed using an Annexin V-FITC/PI Apoptosis Detection Kit and flow cytometry following the manufacturers' instructions. Cell viability was determined using ACEA NovoCyte Flow Cytometer (ACEA Biosciences, Inc., San Diego, CA, USA) with the excitation light and emission light wavelengths set at $488 \mathrm{~nm}$ and $530 \mathrm{~nm}$, respectively. Data were collected and analyzed using NovoExpress software. The cell viability of $D$. wulumuqiensis R12 when using HMF as the substrate is presented as the percentage of living cells to the total amount of cells.

\subsection{Synthesis of HMFCA by the Substrate Fed-Batch Feeding Process}

Five milliliters of $100 \mathrm{mM}$ phosphate buffer,pH 7.0, which contained $150 \mathrm{mM}$ HMF substrate and $0.2 \mathrm{~g} / \mathrm{mL}$ of microbial cells, was incubated at $35^{\circ} \mathrm{C}$ and $850 \mathrm{rpm}$. After $5 \mathrm{~h}, 0.75 \mathrm{mmol}$ of HMF was repeatedly added to the reaction mixture. During the whole biocatalytic process, the $\mathrm{pH}$ of the reaction mixture was adjusted to the range of 7.0-8.0 with $\mathrm{NaOH}$ solution and the concentration of substrate and products was analyzed by HPLC. 


\section{Conclusions}

Herein, we successfully explored for the first time the use of a radiation resistant $D$. wulumuqiensis R12 strain as a whole-cell biocatalyst for the efficient synthesis of HMFCA from HMF. The whole cells of this strain proved to be highly tolerant to HMF and the product, HMFCA. The whole-cell system is an excellent biocatalyst for the selective oxidation of HMF. An excellent yield of HMFCA of up to $90 \%$ was achieved within $36 \mathrm{~h}$ in the presence of $300 \mathrm{mM} \mathrm{HMF}$ substrate under optimized conditions. A yield of $80 \%$ to $66 \%$ was obtained when the substrate concentration increased from $350 \mathrm{mM}$ to $500 \mathrm{mM}$, while the selectivity towards HMFCA remained at approximately $98 \%$. In addition, up to $511 \mathrm{mM}$ of HMFCA was synthesized in $20 \mathrm{~h}$ via a fed-batch method, resulting in a productivity of $44 \mathrm{~g} / \mathrm{L}$ per day. Thus, D. wulumuqiensis R12 cells are a promising catalyst in the biocatalytic process of HMF upgrading. Moreover, the cells were able to transform a set of structurally different aldehyde compounds into their corresponding carboxylic acids with good to excellent selectivity. Since the genome sequence of this strain has been sequenced, exploring the genes that encode the enzymes responsible for HMFCA synthesis from HMF has become feasible in future work. The catalytic properties of these microbial cells can also be further engineered by introduction of other oxidases to form a cell factory for HMF biotransformation. Furthermore, this strain may also have potential applications for the biodetoxification of lignocellulosic hydrolysates in the process of biofuel production. Discovery of D. wulumuqiensis R12 as an efficient biocatalyst broadens the toolbox of biocatalysts for the biotransformation of HMF into value-added derivatives and will further facilitate the utilization of biomass for the production of useful chemicals and biofuels.

Supplementary Materials: The following are available online at http://www.mdpi.com/2073-4344/9/6/526/s1, Figure S1: HPLC measurements: (A) HMF and its derivatives; (B) HMF substrate, HMFCA and BHMF products. Figure S2: Effects of reaction time on HMFCA synthesis. Figure S3: Biocatalytic oxidation of HMF to HMFCA by different Deinococcus strains. Figure S4: Effect of cell concentration on HMFCA synthesis. Figure S5: Optimizing reaction condition for HMFCA synthesis by using various strategies.

Author Contributions: Conceptualization, Z.-G.Z.; investigation, R.C., G.Y. and L.-Q.S.; funding acquisition, Z.-G.Z.; resources, Z.-G.Z.; writing-original draft preparation, Z.-G.Z.; writing-review and editing, H.H. and Z.-D.Z.

Funding: This research was funded by the National Natural Science Foundation of China (No. 21646014, 21776134 and 21776136), the program of Jiangsu Synergetic Innovation Center for Advanced Bio-Manufacture (XTE1851). and The APC was funded by the program of Jiangsu Synergetic Innovation Center for Advanced Bio-Manufacture (XTE1851).

Acknowledgments: We thank Professor Dr. Manfred T. Reetz (Max-Planck-Institut für Kohlenforschung, Germany) for critical reading of the manuscript and helpful comments.

Conflicts of Interest: The authors declare no conflict of interest.

\section{References}

1. Sheldon, R.A. Green and sustainable manufacture of chemicals from biomass: State of the art. Green Chem. 2014, 16, 950-963. [CrossRef]

2. Wu, L.; Moteki, T.; Gokhale, A.A.; Flaherty, D.W.; Toste, F.D. Production of Fuels and Chemicals from Biomass: Condensation Reactions and Beyond. Chem 2016, 1, 32-58. [CrossRef]

3. Tuck, C.O.; Pérez, E.; Horváth, I.T.; Sheldon, R.A.; Poliakoff, M. Valorization of Biomass: Deriving More Value from Waste. Science 2012, 337, 695-699. [CrossRef] [PubMed]

4. Zhang, Z.; Deng, K. Recent Advances in the Catalytic Synthesis of 2,5-Furandicarboxylic Acid and Its Derivatives. ACS Catal. 2015, 5, 6529-6544. [CrossRef]

5. Christensen, C.H.; Rass-Hansen, J.; Marsden, C.C.; Taarning, E.; Egeblad, K. The Renewable Chemicals Industry. ChemSusChem 2008, 1, 283-289. [CrossRef] [PubMed]

6. Gallezot, P. Conversion of biomass to selected chemical products. Chem. Soc. Rev. 2012, 41, 1538-1558. [CrossRef] [PubMed]

7. Isikgor, F.H.; Becer, C.R. Lignocellulosic biomass: A sustainable platform for the production of bio-based chemicals and polymers. Polym. Chem. 2015, 6, 4497-4559. [CrossRef] 
8. Chheda, J.N.; Román-Leshkov, Y.; Dumesic, J.A. Production of 5-hydroxymethylfurfural and furfural by dehydration of biomass-derived mono- and poly-saccharides. Green Chem. 2007, 9, 342-350. [CrossRef]

9. Van Putten, R.-J.; van der Waal, J.C.; de Jong, E.; Rasrendra, C.B.; Heeres, H.J.; de Vries, J.G. Hydroxymethylfurfural, A Versatile Platform Chemical Made from Renewable Resources. Chem. Rev. 2013, 113, 1499-1597. [CrossRef] [PubMed]

10. Teong, S.P.; Yi, G.; Zhang, Y. Hydroxymethylfurfural production from bioresources: Past, present and future. Green Chem. 2014, 16, 2015-2026. [CrossRef]

11. Bozell, J.J.; Petersen, G.R. Technology development for the production of biobased products from biorefinery carbohydrates-the US Department of Energy's “Top 10" revisited. Green Chem. 2010, 12, 539-554. [CrossRef]

12. Rosatella, A.A.; Simeonov, S.P.; Frade, R.F.M.; Afonso, C.A.M. 5-Hydroxymethylfurfural (HMF) as a building block platform: Biological properties, synthesis and synthetic applications. Green Chem. 2011, 13, 754-793. [CrossRef]

13. Koopman, F.; Wierckx, N.; de Winde, J.H.; Ruijssenaars, H.J. Efficient whole-cell biotransformation of 5-(hydroxymethyl)furfural into FDCA, 2,5-furandicarboxylic acid. Bioresour. Technol. 2010, 101, 6291-6296. [CrossRef] [PubMed]

14. Hu, L.; He, A.; Liu, X.; Xia, J.; Xu, J.; Zhou, S.; Xu, J. Biocatalytic Transformation of 5-Hydroxymethylfurfural into High-Value Derivatives: Recent Advances and Future Aspects. ACS Sustain. Chem. Eng. 2018, 6, 15915-15935. [CrossRef]

15. Gandini, A.; Silvestre, A.J.D.; Neto, C.P.; Sousa, A.F.; Gomes, M. The furan counterpart of poly(ethylene terephthalate): An alternative material based on renewable resources. J. Polym. Sci. Part A Polym. Chem. 2009, 47, 295-298. [CrossRef]

16. Sousa, A.F.; Vilela, C.; Fonseca, A.C.; Matos, M.; Freire, C.S.R.; Gruter, G.-J.M.; Coelho, J.F.J.; Silvestre, A.J.D. Biobased polyesters and other polymers from 2,5-furandicarboxylic acid: A tribute to furan excellency. Polym. Chem. 2015, 6, 5961-5983. [CrossRef]

17. Hirai, H. Oligomers from Hydroxymethylfurancarboxylic Acid. J. Macromol. Sci. Part A Chem. 1984, 21, 1165-1179. [CrossRef]

18. Tamura, G. Antitumor Activity of 5-Hydroxy-methyl-2-furoic Acid AU-Munekata, Masanobu. Agric. Biol. Chem. 1981, 45, 2149-2150. [CrossRef]

19. Braisted, A.C.; Oslob, J.D.; Delano, W.L.; Hyde, J.; McDowell, R.S.; Waal, N.; Yu, C.; Arkin, M.R.; Raimundo, B.C. Discovery of a Potent Small Molecule IL-2 Inhibitor through Fragment Assembly. J. Am. Chem. Soc. 2003, 125, 3714-3715. [CrossRef]

20. Casanova, O.; Iborra, S.; Corma, A. Biomass into Chemicals: Aerobic Oxidation of 5-Hydroxymethyl-2-furfural into 2,5-Furandicarboxylic Acid with Gold Nanoparticle Catalysts. ChemSusChem 2009, 2, 1138-1144. [CrossRef]

21. Gorbanev, Y.Y.; Klitgaard, S.K.; Woodley, J.M.; Christensen, C.H.; Riisager, A. Gold-Catalyzed Aerobic Oxidation of 5-Hydroxymethylfurfural in Water at Ambient Temperature. ChemSusChem 2009, 2, 672-675. [CrossRef]

22. Davis, S.E.; Houk, L.R.; Tamargo, E.C.; Datye, A.K.; Davis, R.J. Oxidation of 5-hydroxymethylfurfural over supported Pt, Pd and Au catalysts. Catal. Today 2011, 160, 55-60. [CrossRef]

23. Zhang, Z.; Liu, B.; Lv, K.; Sun, J.; Deng, K. Aerobic oxidation of biomass derived 5-hydroxymethylfurfural into 5-hydroxymethyl-2-furancarboxylic acid catalyzed by a montmorillonite K-10 clay immobilized molybdenum acetylacetonate complex. Green Chem. 2014, 16, 2762-2770. [CrossRef]

24. Zhou, B.; Song, J.; Zhang, Z.; Jiang, Z.; Zhang, P.; Han, B. Highly selective photocatalytic oxidation of biomass-derived chemicals to carboxyl compounds over $\mathrm{Au} / \mathrm{TiO}_{2}$. Green Chem. 2017, 19, 1075-1081. [CrossRef]

25. Subbiah, S.; Simeonov, S.P.; Esperança, J.M.S.S.; Rebelo, L.P.N.; Afonso, C.A.M. Direct transformation of 5-hydroxymethylfurfural to the building blocks 2,5-dihydroxymethylfurfural (DHMF) and 5-hydroxymethyl furanoic acid (HMFA) via Cannizzaro reaction. Green Chem. 2013, 15, 2849-2853. [CrossRef]

26. Kang, E.-S.; Chae, D.W.; Kim, B.; Kim, Y.G. Efficient preparation of DHMF and HMFA from biomass-derived HMF via a Cannizzaro reaction in ionic liquids. J. Ind. Eng. Chem. 2012, 18, 174-177. [CrossRef]

27. Domínguez de María, P.; Guajardo, N. Biocatalytic Valorization of Furans: Opportunities for Inherently Unstable Substrates. ChemSusChem 2017, 10, 4123-4134. [CrossRef] 
28. Zhang, X.-Y.; Zong, M.-H.; Li, N. Whole-cell biocatalytic selective oxidation of 5-hydroxymethylfurfural to 5-hydroxymethyl-2-furancarboxylic acid. Green Chem. 2017, 19, 4544-4551. [CrossRef]

29. Qin, Y.-Z.; Li, Y.-M.; Zong, M.-H.; Wu, H.; Li, N. Enzyme-catalyzed selective oxidation of 5-hydroxymethylfurfural (HMF) and separation of HMF and 2,5-diformylfuran using deep eutectic solvents. Green Chem. 2015, 17, 3718-3722. [CrossRef]

30. Mitsukura, K.; Sato, Y.; Yoshida, T.; Nagasawa, T. Oxidation of heterocyclic and aromatic aldehydes to the corresponding carboxylic acids by Acetobacter and Serratia strains. Biotechnol. Lett 2004, 26, 1643-1648. [CrossRef]

31. Van Rantwijk, F.; Sheldon, R.A. Chloroperoxidase-Catalyzed Oxidation of 5-Hydroxymethylfurfural. J. Carbohydr. Chem. 1997, 16, 299-309. [CrossRef]

32. Krystof, M.; Pérez-Sánchez, M.; Domínguez de María, P. Lipase-Mediated Selective Oxidation of Furfural and 5-Hydroxymethylfurfural. ChemSusChem 2013, 6, 826-830. [CrossRef] [PubMed]

33. Ni, Y.; Xu, J.-H. Biocatalytic ketone reduction: A green and efficient access to enantiopure alcohols. Biotechnol. Adv. 2012, 30, 1279-1288. [CrossRef] [PubMed]

34. Ku, S. Finding and Producing Probiotic Glycosylases for the Biocatalysis of Ginsenosides: A Mini Review. Molecules 2016, 21, 645. [CrossRef] [PubMed]

35. Trudgill, P.W. The metabolism of 2-furoic acid by Pseudomanas F2. Biochem. J. 1969, 113, 577-587. [CrossRef]

36. Koenig, K.; Andreesen, J.R. Xanthine dehydrogenase and 2-furoyl-coenzyme A dehydrogenase from Pseudomonas putida Fu1: Two molybdenum-containing dehydrogenases of novel structural composition. J. Bacteriol. 1990, 172, 5999-6009. [CrossRef]

37. López, M.J.; Nichols, N.N.; Dien, B.S.; Moreno, J.; Bothast, R.J. Isolation of microorganisms for biological detoxification of lignocellulosic hydrolysates. Appl. Microbiol. Biotechnol. 2004, 64, 125-131. [CrossRef]

38. Koopman, F.; Wierckx, N.; de Winde, J.H.; Ruijssenaars, H.J. Identification and characterization of the furfural and 5-(hydroxymethyl)furfural degradation pathways of Cupriavidus basilensis HMF14. Proc. Natl. Acad. Sci. USA 2010, 107, 4919-4924. [CrossRef]

39. Nikel, P.I.; Chavarría, M.; Danchin, A.; de Lorenzo, V. From dirt to industrial applications: Pseudomonas putida as a Synthetic Biology chassis for hosting harsh biochemical reactions. Curr. Opin. Chem. Biol. 2016, 34, 20-29. [CrossRef]

40. Hoover, R.B.; Tang, J. Microbial Extremophiles at the Limits of Life AU - Pikuta, Elena V. Crit. Rev. Microbiol. 2007, 33, 183-209. [CrossRef]

41. Madigan, M.T.; Orent, A. Thermophilic and halophilic extremophiles. Curr. Opin. Microbiol. 1999, 2, $265-269$. [CrossRef]

42. Schiraldi, C.; De Rosa, M. The production of biocatalysts and biomolecules from extremophiles. Trends Biotechnol. 2002, 20, 515-521. [CrossRef]

43. Van den Burg, B. Extremophiles as a source for novel enzymes. Curr. Opin. Microbiol. 2003, 6, $213-218$. [CrossRef]

44. Elleuche, S.; Schröder, C.; Sahm, K.; Antranikian, G. Extremozymes-Biocatalysts with unique properties from extremophilic microorganisms. Curr. Opin. Biotechnol. 2014, 29, 116-123. [CrossRef] [PubMed]

45. Wang, W.; Mao, J.; Zhang, Z.; Tang, Q.; Xie, Y.; Zhu, J.; Zhang, L.; Liu, Z.; Shi, Y.; Goodfellow, M. Deinococcus wulumuqiensis sp. nov., and Deinococcus xibeiensis sp. nov., isolated from radiation-polluted soil. Int. J. Syst. Evol. Microbiol. 2010, 60, 2006-2010. [CrossRef] [PubMed]

46. Hong, S.; Farrance, C.E.; Russell, A.; Yi, H. Reclassification of Deinococcus xibeiensis Wang et al. 2010 as a heterotypic synonym of Deinococcus wulumuqiensis Wang et al. 2010. Int. J. Syst. Evol. Microbiol. 2015, 65, 1083-1085. [CrossRef]

47. Battista, J.R.; Earl, A.M.; Park, M.-J. Why is Deinococcus radiodurans so resistant to ionizing radiation? Trends Microbiol. 1999, 7, 362-365. [CrossRef]

48. Xu, X.; Tian, L.; Xu, J.; Xie, C.; Jiang, L.; Huang, H. Analysis and expression of the carotenoid biosynthesis genes from Deinococcus wulumuqiensis R12 in engineered Escherichia coli. AMB Express 2018, 8, 94. [CrossRef]

49. Xu, X.; Jiang, L.; Zhang, Z.; Shi, Y.; Huang, H. Genome Sequence of a Gamma- and UV-Ray-Resistant Strain, Deinococcus wulumuqiensis R12. Genome Announc. 2013, 1, e00206-e00213. [CrossRef]

50. Liao, Z.; Zhang, Y.; Luo, S.; Suo, Y.; Zhang, S.; Wang, J. Improving cellular robustness and butanol titers of Clostridium acetobutylicum ATCC824 by introducing heat shock proteins from an extremophilic bacterium. J. Biotechnol. 2017, 252, 1-10. [CrossRef] 
51. Wierckx, N.; Koopman, F.; Ruijssenaars, H.J.; de Winde, J.H. Microbial degradation of furanic compounds: Biochemistry, genetics, and impact. Appl. Microbiol. Biotechnol. 2011, 92, 1095-1105. [CrossRef] [PubMed]

52. Palmqvist, E.; Hahn-Hägerdal, B. Fermentation of lignocellulosic hydrolysates. II: Inhibitors and mechanisms of inhibition. Bioresour. Technol. 2000, 74, 25-33. [CrossRef]

53. Knaus, T.; Tseliou, V.; Humphreys, L.D.; Scrutton, N.S.; Mutti, F.G. A biocatalytic method for the chemoselective aerobic oxidation of aldehydes to carboxylic acids. Green Chem. 2018, 20, 3931-3943. [CrossRef]

54. Pang, C.; Zhang, J.; Zhang, Q.; Wu, G.; Wang, Y.; Ma, J. Novel vanillic acid-based poly(ether-ester)s: From synthesis to properties. Polym. Chem. 2015, 6, 797-804. [CrossRef]

(C) 2019 by the authors. Licensee MDPI, Basel, Switzerland. This article is an open access article distributed under the terms and conditions of the Creative Commons Attribution (CC BY) license (http://creativecommons.org/licenses/by/4.0/). 